\title{
DO STUDENT-TEACHERS PROVIDE PRODUCTION IN TEYL IN INDONESIA?
}

\author{
Rusiana, Nuraeningsih \\ rusiana@umk.ac.id,nuraeningsih@umk.ac.id \\ Muria Kudus University
}

\begin{abstract}
Teaching English to Young Learners (TEYL) in Indonesia is recognizably unsatisfactory. Students' English proficiency has not met with the demand. What the students learn in Primary School seem not give any help in coping with English in Secondary School. Things to be reflected is the way the students learn or a bit suspect is how the teachers teach. The observable situation is that Indonesian classes especially Young Learners classes are not provided with production

which is actually the soul of the learning. It is the stage of teaching that require students to produce the target language orally or in written. When production does not present in class, students are not provided with opportunities to use the language which simply leads them to be passive learners. Consequently, the target languages are not produced and remaining receptive and they do not use English for communication. The students do not find any challenge and do not feel success learning language since they are not required to produce the target language. Grammar and vocabularies tend to be taught explicitly. On the other hand production seemed to be neglected. This phenomenon interests us to figure out whether student teachers address production in TEYL and what kinds of practices they provide if production takes place. The student teachers in this research are those who joined Teaching Design for Young Learner course. This present research is qualitative research investigating whether or not student teachers address production in teaching YL. The participants were 6 student teachers who were teaching EYL as a project of Teaching Design for Young Learners course. The videotaped were analyzed based on CEFR to see whether production took place in English teaching and what kinds of practices they provided. For triangulation, the student teachers were interviewed separately. The findings showed that 3 participants had provided production in teaching EYL, 2 participants had not provided production yet, and 1 participant provided inappropriate production. The practices they mostly used were oral production, exchanging information between friends.
\end{abstract}

Keywords: production, TEYL, Indonesian English classes

\section{INTRODUCTION}

Many researches on teaching English to Young Learners have been conducted. Yet, they mostly focus on teaching strategies on how to teach EYL such as teaching EYL by using song, games, and so forth. It cannot be denied that teaching EYL have to be fun and enjoyable. However, it does not mean that teaching EYL is something easy and simple without any target. Teaching EYL appropriately can be a good investment for better acquisition. Yet, introducing English earlier does not always guarantee that learners are able to use the target language better. They 
may store a hundred of vocabularies but still they may find it difficult or cannot use them for communication. Lack of exposure is often accused to be one of factors preventing students to use the language. English is only taught in formal class and rarely or even never to be around the students' life.

When teaching EYL accentuates only on storing vocabularies and grammar-oriented, expecting YL speak or write English will be a bit impossible. Unfortunately, the assumption that teaching EYL is emphasized on teaching vocabulary seems to be broadly misbelieved by not only parents but also teachers. It then misleads teaching practices of YL. The learning objectives that should have been the soul for the learning are often forgotten. Vocabularies are given in a loose-context and mostly students are trained with meaningless exercises. No target languages are established to be achieved by the students in the end of learning. Teachers perceived that YL are not been able yet to produce language orally or in written.

The aforementioned might cause level of English proficiency of Indonesian students are not satisfying. Rucks (2015) stated that based on proficiency-oriented perspective, encouraging learners to use the target language to communicate meaningfully regardless to their age is the goal of language teachers. In other words, no matter how early YL start learning English, having the learners to use the target language is necessary.

This present research investigates whether student teachers provide free practice to facilitate students to produce the target language in the end of learning. The student teachers are third year students of college who fulfill a project of Teaching Design to Young Learners course. The project was teaching students in formal or informal class. Usually, student teachers seem struggle to design activities for learning. Therefore, we are interested in investigating whether or not the student teachers give opportunity for students for producing the target language production) at the end of class meeting. Since they are prepared to be English teachers, this research is a worth effort in order to gain a greater understanding of the real practices and alternative solutions or recommendations that might be proposed based on the findings. The questions addressed in this research are: Do student teachers provide production in TEYL in Indonesia? And, what activities that the student teachers provide for production?

\section{LITERATURE REVIEW}

\section{CEFR (Common European Framework Reference)}

This term is generally used to navigate student proficiency continuum. As an attempt to help students develop fluency and accuracy, teachers can provide meaningful activities with contextual vocabulary to support communication, ensuring errors not to be fossilized, drawing attention to inaccurate language use, providing students with strategies to avoid using English with insufficient vocabulary. CEFR is also useful for some purposes, such as developing syllabus, marking exams, designing courses, describing language components, teacher training program, and so forth (Cambridge, 2013).

Regarding to TEYL, particularly this issue, one of key concepts that need to be addressed in this research is applying knowledge and skills. For daily practice, students need opportunities to apply their knowledge and skills in oral production, written production, aural comprehension and reading comprehension in relevant situations that focus on a communicative goal (CEFR, 2001) In oral production, teachers need to reflect the importance of asking questions that provide students with opportunities to demonstrate their proficiency, providing opportunities for students to react, allowing candidates to demonstrate the ability to begin and end interactions, and providing "think time" as required. While in written production, teachers reflected on the 
importance of asking questions that encourage students to demonstrate their proficiency, understanding of the topic, ability to request and provide information, etc.

The Council of Europe classified language production activities (CEFR, 2001: 58-90) into three types; they are oral production, spoken interaction, and oral meditation. The one that fits to TEYL is oral production. Müller-Hartmann / Schocker-von Ditfurth (2007) provide complete explanations about them as the following:

1. Oral production that is producing an oral text for one or more listeners, for example giving information to an audience in a public address. This may involve reading a written text aloud, speaking from notes, acting out a rehearsed role, speaking spontaneously, improvising $[\ldots]$ or singing a song.

2. Spoken interaction that is 'the language user acts alternately as speaker and listener with one or more interlocutors' so as to construct conjointly, through the negotiation of meaning $[\ldots]$ conversational discourse. Reception and production strategies are employed constantly during interaction. There are also [...] discourse strategies and cooperation strategies concerned with managing co-operation and interactions such as turn taking and turn giving, [...] proposing and evaluating solutions, recapping and summarising the point reached, and mediating in a conflict . Examples of interactive activities include conversation, discussion, debate, interview or negotiation.

3. Oral mediation', that is the language user does not express his or her own meanings but 'acts as an intermediary between interlocuters who are unable to understand each other directly - normally [...] speakers of different languages' . Examples of mediating activities include spoken interpretation or summarising and paraphrasing texts. Contexts include simultaneous or consecutive interpretation at conferences or meetings, informal interpreting for foreign visitors, for friends, family clients etc.

(Müller-Hartmann / Schocker-von Ditfurth, 2007: 62 f.)

Further Muller-Hartmann/ Schocker-von Ditfurth (2007) divided speaking activity into 2 kinds; fluency-based activities and accuracy based activities. Some activities classified as fluency-based activities are free discussions, role-plays, information-gap activities, opinion-gap activities. Whereas accuracy-based activities concentrates on building language aspects to students, such as the grammar mastery, communicative function, etc.

Some research have been conducted to know the effectiveness of using CEFR to develop students' language proficiency. First is Glover (2011), which found that the students used CRL statements to write longer, more relevant, and more detailed and critical descriptions of their speaking skills. While, Alderson et al (2009) investigating the Dutch CEFR construct project found that a critical review of the CEFR, a set of compilations of CEFR scales and of test specifications at the different CEFR levels, and a series of frameworks or classification systems, which led to a Web-mounted instrument known as the Dutch CEFR Grid.

\section{METHOD}

This present research is qualitative research investigating the practices of student teachers in teaching primary school aged students to figure out whether or not the student teachers provide production in teaching English to YL. The number of participants was 6 student teachers. The student teachers were doing a project of Teaching Design for Young Learners course which required them to teach real class, formal or informal. Then they had to videotape the teaching practice. Interested to know whether student teachers applied what they got in class about the importance of production in teaching English, I analyzed the videotape and chose 6 videotaped 
randomly. CEFR is used to determine whether or not production takes place in teaching and learning process. After observing the videotaped, then the student teachers were interviewed gain answers on what topic, learning objectives, target language, media, practices, and what kinds of production in their teaching practice. During the interview the videotaped was also shown to the participants in order to clarify and get a crystal clear understanding on the teaching practice.

\section{FINDINGS AND DISCUSSION}

After analyzing the videos, the findings are explained. There were 6 participants in this current research. All of the participants had determined the target language and the learning objectives based on the topic appropriately. For instance, for topic color, the target language was what color is this? This is....(red). Media also had been employed to help the students achieve the target language. Picture was the dominant media. Other media used were realia, cards, ball, slide show, dice, written paper, etc. Practices that had been provided were more than one practice. The six student teachers had been aware and well-acknowledged about the importance of production. The teaching and learning process are presented in detail as follows. The names of the student teachers are pseudonym. They would be called as Amy (student teacher 1), Bintang (student teacher 2), Caca (student teacher 3), Doni (student teacher 4), Endang (student teacher 5), and Fina (student teacher 6).

\section{Student teacher 1}

The first student teacher, Amy, was teaching about feelings. The observable situation from the recordings showed that production did not take place in the teaching practice. She had addressed the target language and the learning objectives appropriately that was What do you feel today? I feel happy. Unfortunately, the practices that she provided had not met with the learning objective that the students had to be able to ask and answer on What do you feel today? I feel happy. The practices were still accuracy oriented. She began the class by getting the students to sing along. Then she explained the learnt topic while showing pictures of feelings. Then, she taped the pictures on the board and had the students write the words on the board on the corresponding picture. She encouraged the students by asking a question, what do you feel today? while pointing to the board. Another practice was the teacher uttered a sentence, I feel angry, and the students gave number to the corresponding picture, still on the board. The last, Amy wrote about five sentences of the target language and let the students tape the corresponding pic on the board.

\section{Student teacher 2}

The second student teacher, Bintang, was teaching about color. She had properly established the target language and the learning objective. She also began the class by getting the students to sing along as what Amy did. Then she showed a colorful dice. When the students rolled the dice and got blue color, they had to tape a piece of paper on the board on the corresponding words that had been written. She encouraged the students to use the target language initially in this stage, what color is it? This is purple. Another media came out, a color paper stick. Different words were written on the color paper such as one with red color was written blue. Again, she used the target language. The students were challenged to concentrate on what color that they really saw. Further, Bintang gave one picture for each student and had them color the picture by using the instructed color; Alif, you will color the grapes orange, while letting the student take the right marker, and so forth. In the end, the students in pair were asked to come forward and asked and answered using the target language. The first pair many times slipped tongue in saying 
what color is this? to be what color this is? It is obvious that Bintang addressed production in her practice.

\section{Student Teacher 3}

Caca was teaching about telling time. She began the meeting by doing an icebreaking. Getting the students to clap hands based on the parts of body that she touched for example nose for one clap, etc. Then she asked one of the students, what time did you sleep last night? while asking them to put the right minute hand The girl student responded in Indonesian. Caca directly asked the students what time is it?. The digital was written on the board. While explaining, Caca asked the students. Then she had the students in pair asked and answer using the target language. Many times she told the students to use Indonesian when she saw them spoke hesitantly. If the first the media used was paper clock with minute hand, the second practice used digital style of clock written on a small rectangle shaped paper taped on the board. Next, the students again were asked in pair to ask and answer what time is it? It is ..(seven past thirty). The practices were all production. It seemed not help the students to produce the target language independently in the end of the meeting since Caca always gave hot correction from the beginning to the end.

\section{Student teacher 4}

Doni was teaching about food. The established target language was what food do you like? I like...(noodle). The learning objective was that the students were able to mention kinds of food and ask and answer by using the target language. Initially, the students were asked to introduce themselves individually including what food they like. I like fried rice, one student said. Doni was showing slides of food and at the same time asking the students whether they like the food on the slide. The students then did a survey asking their friends of what food they like. They will put a tick and cross to represent yes or no based on their friend's answer. Before, they had written the name of the food on the list based on the pictures on the slide. The production took place in Doni's class. Yet, the practices had not been designed to support the production. It was only one practice preceding the production, writing the names of food.

\section{Student teacher 5}

Production took place in this teaching practice. Yet it did not take place in the end of teaching practice. The target language and the learning objective had been set. Yet, the part that Endang admitted to be production was a bit different with the target language. She was teaching about animal sound. She began with passing ball game. One of the question addressed to the student who held the ball when the music stopped was what animal do you like? It is a ...(rabbit). Other questions were varied, not only about animal. Then she was showing pictures of animals and drill the students, it is a cow, it is a bird, it is a duck, etc. Another practice required students in pair to sound like a certain animal and the other student answer for example roar...roar... what sound do you hear? It is a snake. Similarly, the students in pair mime out and guess the animal's sound. Then students filled the missing letter on the board.

\section{Student teacher 6}

The sixth participant, Fina, was teaching about animal. Icebreaking was noticeably used for getting the students' attention. She mimed out animals and the students answered what animal it is. A set of animal pictures were shown and the students were asked, is it a lion? while showing another animal, and so forth to elicit yes and no response. Those picture were then given to the students to be taped on the board. The first practice was listen and number. The students wrote 
the number on the corresponding picture based on the sentences that the teacher read. The students came forward and put the names of animals on the picture that had been taped on the board before. After writing only the names for example lion, they wrote the full sentence, it is a lion. Fina was always asking the one who was coming forward with the target language. The last practice was one student came to the front and asked the rest students using the target language while pointing to the pictures.

Based on the findings above, oral production seemed not take place in Amy and Fina's teaching practice. It was indicated by the absence of activities demanding the students to use the target language in the end of the meeting. When the two student teachers were interviewed, they admitted that what prevented them not to provide production were due to the limited time, classroom management, student's barrier (e.g the students are ashamed to deal with the activity provided by the teacher, the students were a bit out of control because of being tempted to do something else such as drawing). Meanwhile, Caca tend to set the activities redundantly. The students had been required to produce the target language in the very beginning of the meeting and continued to the rest two activities. So when fluency based activities were allocated inappropriately, it could discourage students to be reluctant and less confident. They need time for internalizing the language with the teacher's help that is through graded practices. Here all activities were production, the students were asked to exchange information in the three activities.

The rest three student teachers had provided production. The practice that they provided were asking and answering based on the target language in pair. It belongs to information-gap activities (involve transfer of given information from one person to another) CEFR (2001: 5890). Based on the interview, the student teachers were well acknowledged with the importance of production. They all agreed that production were needed to provide the students an experience to use the language. Without production, they would not able to see whether the students got the idea of what they were learning.

\section{CONCLUSION AND SUGGESTION}

Referring back to the first research question whether student teachers provide production in Teaching English to YL, it clearly showed that four of them had addressed production, two of them had not provided any production, and one had addressed production redundantly. All of them had been aware to provide graded practices. Yet, because of limited time that they had to fulfill in doing this practice, some practices were left. Other reasons that prevented them not to provide production were due to classroom management, student's barrier (e.g. the students are ashamed to deal with the activity provided by the teacher, the students were a bit out of control because of being tempted to do something else such as drawing).

Another research question is that what activities the student teachers provide if there is any. From the observable situation, the practice used in production was information gap activities in which one student asked another one or others using the target language of the day. The students were given an opportunity to use the language. Through this way, the students will feel success in learning language. It also enables them to acquire language since they are encouraged to use the language in a real communication by interacting and socializing with friends. Halliday (1973, 1975) states that it is an active process in which children learn language to show their existence in their world by socializing with others. 
To sum up, teaching English to YL does not mean teaching simple material without any target to be achieved. The presence of production is a must. To set an appropriate practice for production, preceding practices should be also considered in order to help the students produce the target language smoothly. It is necessary to establish the learning objective, target language, graded practices/activities, and production to promote students' English proficiency. To bear in mind, language needs to be associated to pleasant activities in order to stimulate young learners to talk. Young learner's oral language develops when the environment provide natural need to communicate (Morrow). There is no way to acquire language but to use it. When production is always provided in YL class, students will be ready for the demand of any target in English. Therefore, student teachers as prospective teachers need to be aware with this issue.

\section{REFERENCES}

CEF (2001) Common European Framework of Reference: Learning, Teaching and Assessment,(CEFR)

http://www.coe.int/t/dg4/linguistic/Source/SourcePublications/CEFR_SupportingDocs_EN.pdf

Council of Europe.(2001a). Common European Framework of Reference : Learning, teaching and assessment. Cambridge : Cambridge University Press

Garret-Rucks, P. (2015). Evidence-Based principle for the design of computer mediated cultural instructions. In P. Swanson \& S. Li (Eds) in Engaging Language Learners through Technology Integration: Theory, Application and Outcomes. IGI Global

Halliday, M.A.K.(1973). The Functional basis of language. In Brazil Bernstein (Ed). Applied Studies towards Sociology of Languages, Vol.2, Class, Codes and Control. Roudledge \& Kegan Paul. 343-66.

.(1975). The context of linguistics. In Francis P. Dinneen (Ed.). Report of Twenty Fifth Annual Round Table Meeting on Linguistics and Language Studies, Monograph series on Language and Linguistics 17. Georgetown University Press.

Morrow, Lesley Mendel. (2015). Literacy in Early Years: Helping Children Read and Write, Enhanced Person e--Text Access Card 8th Edition.New Jearsey: Pearson

MullerHartsman Schocker-van Diftuks, Merita. (2007). Introduction to English Language Teaching. EN/Y 20084915(6).

Wilkins, D.A. (1972). Linguistics in Language Teaching. London: Arnold

http://www.tandfonline.com/doi/abs/10.1207/s15434311laq0301_2?src=recsys (accessed on 20 April 2017)

http://www.tandfonline.com/doi/abs/10.1080/09658416.2011.555556_ (accessed on 20 April 2017)

http://scolt.org/index.php/publications/dimension/26-publications/39-scolt-publications (accessed on 20 April 2017) 